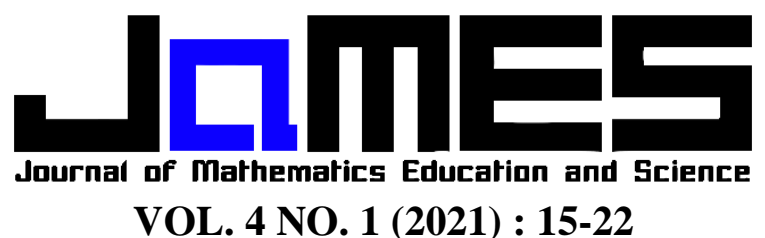

p-ISSN: 2621-1203 | https://doi.org/10.32665/james.v4i1.171 | e-ISSN: 2621-1211

\title{
FLIPPED CLASSROOM : PENINGKATAN KEMAMPUAN BERPIKIR KRITIS MATEMATIS DAN MOTIVASI BELAJAR PESERTA DIDIK MADRASAH TSANAWIYAH
}

\author{
Shafira Fiscarina Widyasari ${ }^{1}$, Rubhan Masykur², Iip Sugiharta ${ }^{3}$ \\ Universitas Islam Negeri Raden Intan Lampung, shafirafws@gmail.com ${ }^{1}$ \\ Universitas Islam Negeri Raden Intan Lampung, rmasykur@yahoo.co.id ${ }^{2}$ \\ Universitas Islam Negeri Raden Intan Lampung, iipsugiharta@ radenintan.ac.id ${ }^{3}$ \\ Received : 27 November 2020, Revised : 26 April 2021, Accepted : 27 April 2021
}

(C) Mathematics Education Unugiri 2021

\begin{abstract}
This study aims to improve students' mathematical critical thinking skills and learning motivation through the Flipped Classroom learning model. This research is a kind of Quasi-Experimental Design research. The population in this study were students of class VIII MTs Al Khairiyah Agom, sampling using the Cluster Random Sampling technique obtained two classes from several VIII classes at MTs Al-Khairiyah Agom. As a sample, the experimental class uses flipped classroom, while the control class is learning using the expository learning model. Analysis of the data used in this study used the MANOVA test with the R program. Based on the research analysis results, there was an effect of flipped classroom learning on improving mathematical critical thinking skills and learning motivation of students. The essential mathematical skills of thinking and learning motivation of students who use flipped classroom learning are better than the mathematical critical thinking skills of students who use expository knowledge.
\end{abstract}

Keywords: Flipped Classroom, Mathematical Critical Thinking, Motivation to Learn.

\begin{abstract}
Abstrak
Penelitian ini bertujuan untuk meningkatkan kemampuan berfikir kritis matematis dan motivasi belajar peserta didik melalui model pembelajaran Flipped Classroom. Penelitian ini merupakan penelitian jenis Quisi Experimental Design. Populasi pada penelitian ini yaitu peserta didik kelas VIII MTs Al Khairiyah Agom, pengambilan sampel menggunakan teknik Cluster Random Sampling didapat dua kelas dari beberapa kelas VIII di MTs Al-Khairiyah Agom. Sebagai sampel kelas eksperimen yaitu pembelajaran menggunakan flipped classroom, sedangkan kelas kontrol yaitu pembelajaran menggunakan model pembelajaran ekspositori. Analisis data yang digunakan dalam penelitian ini menggunakan uji MANOVA dengan program $R$. Berdasarkan hasil analisis penelitian terdapat pengaruh pembelajaran flipped classroom terhadap peningkatan kemampuan berpikir kritis matematis dan motivasi belajar peserta didik. Kemampuan berpikir kritis matematis dan motivasi belajar peserta didik yang menggunakan pembelajaran flipped classroom lebih baik dibandingkan kemampuan berpikir kritis matematis peserta didik yang menggunakan pembelajaran ekspositori.
\end{abstract}

Kata kunci: Flipped Classroom, Berpikir Kritis Matematis, Motivasi Belajar.

\section{Pendahuluan}

Berpikir kritis matematis merupakan suatu proses sistematis dan terorganisasi yang memungkinkan seseorang untuk merumuskan dan mengevaluasi keyakinan, bukti, asumsi, logika dan pendapatnya sendiri yang mendasari pernyataan yang diterimanya [1]. Berpikir kritis adalah pemikiran yang masuk akal dan reflektif untuk dapat memutuskan sesuatu yang di fokuskan untuk menentukan pemikirannya dapat diyakini atau dilakukan yang didasari dengan pemikiran ilmiah [2]. Kemampuan berpikir kritis sangat menentukan keberhasilan pemecahan masalah. Pengembangan 
kemampuan berpikir kritis peserta didik dibutuhkan dalam proses pembelajaran matematika [3]. Kemampuan berpikir kritis matematis adalah aktifitas berpikir yang dilakukan menggunakan langkah langkah metode ilmiah dalam bidang matematika [4]. Dalam proses pembelajaran matematika tidak hanya kemampuan berfikir kritis peserta didik yang ditingkatkan. Namun, motivasi belajar perlu ditingkatkan dalam proses pembelajaran matematika.

Motivasi dalam proses belajar sebagai daya penggerak di dalam diri siswa yang akan menimbulkan kegiatan belajar dengan berbagai perasaan atau keadaan, sehingga tujuan yang diinginkan oleh peserta didik dapat tercapai dengan baik [5]. Motivasi pada dasarnya dapat membantu dalam memahami dan menjelaskan perilaku individu, termasuk perilaku individu yang sedang belajar [6]. Motivasi adalah proses yang memberi semangat, arah dan kegigihan perilaku. Artinya, perilaku yang termotivasi adalah perilaku yang penuh energy, terarah dan bertahan lama [7]. Motivasi mempunyai kedudukan yang sangat penting dalam mencapai tujuan pembelajaran. Motivasi menjadikan peserta didik semangat sehingga peserta didik dapat mengetahui arahnya belajarnya [8].

Kenyataan dilapangan Terkait hasil Prasurvey di MTs Al-Khairiyah Agom, peneliti telah melakukan wawancara kepada salah satu pendidik matematika kelas VIII di sekolah tersebut beliau menjelaskan bahwa kemampuan berpikir kritis matematis peserta didik masih tergolong rendah. Hal ini terlihat dari hasil ulangan harian yang menyatakan sebagian dari peserta didik nilainya masih di bawah rata-rata dan hanya beberapa peserta didik yang memperoleh nilai diatas KKM. Hasil ulangan peserta didik merupakan hasil belajar. Dimana kemampuan berpikir kritis yang dimiliki peserta didik berkaitan dengan hasil belajarnya. Semakin tinggi kemampuan berpikir kritis dan motivasi peserta didik maka dapat meningkatkan hasil belajar peserta didik tersebut [9].
Penelitian-penelitian terdahulu pemahaman konsep matematis siswa yang diterarapkan model Flipped Classroom lebih baik dari kemampuan pemahaman konsep yang diterapkan dengan metode ceramah atau konvensional [10, 11]. Hasil setiap perubahan satu satuan motivasi belajar siswa akan diikuti oleh meningkatnya hasil belajar siswa [10]. Perbedaan penelitian ini dari penelitianpenelitian sebelumnya adalah peneliti menambahkan audio visual untuk melihat motivasi belajar siswa dengan model Flipped Classroom.

Hasil ulangan setiap kelompok yang dibawah KKM terdapat sebanyak 66 siswa yang belum mencapai KKM dan 24 peserta didik yang sudah mencapai KKM. Sementara KKM mata pelajaran matematika di MTs AlKhairiyah Agom yaitu 72. Hal ini menunjukan kemampuan berpikir kritis matematis masih tergolong rendah.

Pendidik perlu melakukan inovasi baru dalam proses pembelajaran untuk bisa mengatasi masalah rendahnya kemampuan berfikir kritis matematis dan motivasi belajar peserta didik. flipped classroom adalah salah satu cara yang terdapat pada proses pembelajaran dimana meminimalisir suatu kegiatan pembelajaran di dalam kelas namun memaksimalkan interaksi satu sama lain yaitu guru, peserta didik serta lingkungannya. Flipped classroom adalah suatu proses belajar yang sebelum kelas dimulai materi pelajaran sudah dipelajari oleh peserta didik pada saat dirumah dan kegiatan belajar mengajar di dalam kelas hanya berupa pemberian tugas dan mengerjakan tugas tersebut, apabila terdapat materi ataupun masalah yang pesert didik belum pahami maka akan di lakukan kegiatan diskusi [11]. Model flipped classroom menjadikan hal yang biasanya diselesaikan di kelas dan apa yang biasanya diselesaikan di rumah ditukar atau dibalik. Pekerjaan rumah seperti pemecahan masalah lebih baik dikerjakan di kelas dengan bimbingan guru menjadi prinsip flipped classroom [12]. Flipped Classroom merupakan pendekatan aktif yang berpusat pada siswa untuk meningkatkan kualitas 
pembelajaran di kelas [13]. Flipped Classroom merupakan model pembelajaran dengan menggunakan media video pembelajaran. Model flipped classroom adalah proses pembelajaran di mana siswa diharuskan membaca atau melihat video di rumah sebelum atau setelah kelas dimulai [14]. Flipped classroom, yang pada intinya memindahkan pembelajaran ke luar kelas melalui teknologi dan menyimpan pekerjaan rumah dan latihan dengan konsep di dalam kelas melalui kegiatan pembelajaran [15].

Pembelajaran flipped classroom untuk kemampuan berpikir kritis matematis dan motivasi belajar peserta didik ini akan lebih baik apabila dikombinasikan dengan bantuan media audio visual untuk memudahkan peserta didik dalam proses pembelajaran. Penggunaan media audio visual berupa video pembelajaran membuat proses pembelajaran lebih menarik sehinga dapat meningkatkan kemampuan berpikir kritis peserta didik. Media audio visual juga berperan terhadap peningkatan motivasi belajar peserta didik, dengan adanya media audio visual peserta didik aktif selama proses pembelajaran sehingga menunjang ketuntusan belajar [16]. Selain itu, media audio visual salah satu cara yang dapat menumbuhkan kerjasama dan kreativitas peserta didik sehingga meningkatkan hasil belajar peserta didik [17].

\section{Metode Penelitian}

Metode yang di gunakan dalam penelitian ini adalah Quasi Experimental Design atau eksprimen semu. Pada pelaksanaannya terdapat dua kelompok yaitu kelompok eksperimen dan kontrol. Kelompok pertama merupakan kelompok eksperimen, yaitu peserta didik yang mendapatkan perlakuan pembelajaran matematika menggunakan model pembelajaran Flipped Classroom berbantuan media Audio visual dalam meningkatkan kemampuan berpikir kritis matematis dan motivasi belajar peserta didik. Sedangkan kelompok kedua merupakan kelompok kontrol, yaitu peserta didik yang mendapat perlakuan pembelajaran matematika dengan model ekspositori. Desain penelitian dalam penelitian ini yaitu prestest-posttest control group design. Dimana sebelum dilakukan perlakuan kelas kelas eksperimen dan kelas konrol diberikan pretest sebagai tes awal dan selanjutnya diberikan posttest, dapat dilihat pada Tabel 2.

Tabel 2. Desain Penelitian Prestest-Posttestcontrol Group Design

\begin{tabular}{cccc}
\hline Kelas & Pretest & Perlakuan & Posttest \\
\hline $\begin{array}{c}\text { Kelas } \\
\text { Eksperimen } \\
\text { Kelas }\end{array}$ & $O_{1}$ & $X$ & $O_{2}$ \\
Kontrol & $O_{3}$ & - & $O_{4}$ \\
\hline
\end{tabular}

Pengambilan sampel dilakukan dengan teknik sampling yaitu dua kelas dari beberapa kelas VIII MTs Al-Khairiyah Agom. Pengumpulan data yang digunakan yaitu wawancara, tes, angket, observasi, dan dokumentasi. Instrumen penelitian yang digunakan ialah tes kemampuan berpikir kritis matematis, serta angket motivasi belajar. Penelitian ini menggunakan uji instrumen penelitian berupa uji validitas, uji reliabilitas, uji tingkat kesukaran dan uji daya pembeda. Teknik uji hipotesis yang akan digunakan dalam penelitian ini adalah Multivariate Analysis of Varians atau yang sering dikenal dengan MANOVA. Pengujian hipotesis dalam penelitian ini menggunakan bantuan $\operatorname{program} R$.

\section{Pembahasan}

Penelitian merupakan kegiatan yang dilakukan untuk mendapatkan data dari suatu percobaan. Uji coba instrumen penelitian telah di lakukan di MTs Al-Khairiyah Agom. Data pada penelitian ini mencakup uji coba instrumen tes kemampuan berpikir kritis matematis dan angket motivasi belajar peserta didik. Pada penelitian yang dilakukan ini bertujuan untuk mengetahui peningkatkan kemampuan berpikir kritis matematis dan motivasi belajar peserta didik melalui model pembelajaran Flipped Classroom.

Pengambilan data dilakukan sebelum proses pembelajaran (pretest) dan setelah dilakukannya pembelajaran (posttest) pada materi relasi dan fungsi. Sebelum melakukan 
pretest dan posttes peneliti telah melakukan wawancara untuk mengetahui apa masalah yang terdapat disekolah terhadap hasil belajar matematika. Setelah data kemampuan berpikir kritis matematis dan motivasi belajar terkumpul, selanjutnya data tersebut digunakan untuk menguji hipotesis penelitian.

Data pretest kemampuan berpikir kritis matematis dan motivasi belajar tersebut selanjutnya dicari nilai terendah $\left(x_{\min }\right)$ dan nilai tertinggi $\left(x_{\text {maks }}\right)$ serta nilai rata-ratanya $(\bar{x})$ yang dirangkum pada Tabel 3 .

Tabel 3. Data Skor Pretest Berpikir Kritis Matematis dan Motivasi Belajar

\begin{tabular}{|c|c|c|c|}
\hline \multirow[b]{2}{*}{ Kelas } & \multirow[b]{2}{*}{ Nilai } & \multicolumn{2}{|c|}{ Variabel } \\
\hline & & $\begin{array}{c}\text { Berpikir } \\
\text { Kritis } \\
\text { Matematis }\end{array}$ & $\begin{array}{c}\text { Motivasi } \\
\text { Belajar }\end{array}$ \\
\hline \multirow{3}{*}{ Eksperimen } & Min & 16 & 31 \\
\hline & Maks & 50 & 55 \\
\hline & $\bar{x}$ & 28,267 & 42,467 \\
\hline \multirow{3}{*}{ Kontrol } & Min & 14 & 32 \\
\hline & Maks & 39 & 50 \\
\hline & $\bar{x}$ & 26,450 & 40,133 \\
\hline
\end{tabular}

Tabel 3 data skor pretest berpikir kritis matematis dan motivasi belajar menunjukkan hasil terdapat perbedaan rata-rata hanya 1,817 dan 2,334 antara kelas eksperimen dan kelas kontrol serta dari hasil observasi dilapangan motivasi belajar siswa terhadpa materi matematika baik kelas kontrol maupun eksperimen masih cukup rendah.

Tabel 4. Data Skor Posttest Berpikir Kritis Matematis dan Motivasi Belajar

\begin{tabular}{cccc}
\hline \multirow{2}{*}{ Kelas } & Nilai & \multicolumn{2}{c}{ Variabel } \\
\cline { 2 - 4 } & & $\begin{array}{c}\text { Kerpikir } \\
\text { Matematis }\end{array}$ & $\begin{array}{c}\text { Motivasi } \\
\text { Belajar }\end{array}$ \\
\hline \multirow{3}{*}{ Eksperimen } & Min & 68 & 75 \\
\cline { 2 - 4 } & Maks & 89 & 85 \\
\cline { 2 - 4 } Kontrol & $\bar{x}$ & 80,300 & 80,350 \\
\hline \multirow{3}{*}{ Min } & 50 & 50 \\
\cline { 2 - 4 } & Maks & 79 & 75 \\
\cline { 2 - 4 } & $\bar{x}$ & 66,033 & 65,800 \\
\hline
\end{tabular}

Data posttest kemampuan berpikir kritis matematis dan motivasi belajar tersebut selanjutnya dicari nilai terendah $\left(x_{\min }\right)$ dan nilai tertinggi $\left(x_{m a k s}\right)$ serta nilai rata-ratanya $(\bar{x})$ yang dirangkum pada Tabel 4. Data skor $N$ Gain kemampuan berpikir kritis matematis dan motivasi belajar tersebut selanjutnya dicari nilai terendah $\left(x_{\min }\right)$ dan nilai tertinggi $\left(x_{\text {maks }}\right)$ serta nilai rata-ratanya $(\bar{x})$ yang dirangkum pada tabel 5. berikut.

Tabel 5. Data Skor N-Gain Berpikir Kritis Matematis dan Motivasi Belajar

\begin{tabular}{|c|c|c|c|}
\hline \multirow[b]{2}{*}{ Kelas } & \multirow[b]{2}{*}{ Nilai } & \multicolumn{2}{|c|}{ Variabel } \\
\hline & & $\begin{array}{c}\text { N-Gain } \\
\text { Berpikir } \\
\text { Kritis } \\
\text { Matematis }\end{array}$ & $\begin{array}{l}\text { N-Gain } \\
\text { Motivasi } \\
\text { Belajar }\end{array}$ \\
\hline \multirow{3}{*}{ Eksperimen } & Min & 0,500 & 0,467 \\
\hline & Maks & 0,861 & 0,739 \\
\hline & $\bar{x}$ & 0,720 & 0,657 \\
\hline \multirow{3}{*}{ Kontrol } & Min & 0,333 & 0,400 \\
\hline & Maks & 0,734 & 0,632 \\
\hline & $\bar{x}$ & 0,536 & 0,530 \\
\hline
\end{tabular}

Dari tabel 5. dapat dilihat data $\mathrm{N}$-Gain untuk kelas eksperimen untuk variabel berpikir kritis matematis diperoleh nilai minimal 0,500 dan nilai maksimal 0,861 serta rata-ratanya yaitu 0,720 . Sedangkan untuk variabel motivasi belajar didapatkan nilai minimal 0,467 dan nilai maksimal 0,739 dengan nilai rata-rata 0,657. Kelas kontrol pada variabel berpikir kritis matematis diperoleh nilai minimal 0,333 dan nilai maksimal 0,734 serta rata-ratanya yaitu 0,536 . Sedangkan untuk variabel motivasi belajar didapatkan nilai minimal 0,400 dan nilai maksimal 0,632 serta nilai rata-ratanya yaitu 0,530 .

Sebelum melakukan uji hipotesis, terlebih dahulu dilakukan uji prasyarat hipotesis. Uji prasyarat tersebut meliputi uji normalitas dan uji homogenitas. Uji normalitas merupakan uji prasyarat yang harus dilakukan untuk mengetahui apakah populasi data berdistribusi normal atau tidak. Uji normalitas menggunakan metode Liliefors terhadap kemampuan berpikir kritis matematis dan motivasi belajar peserta didik dengan dengan taraf signifikansi $5 \%$ dan $L_{\text {hitung }}$ untuk setiap kelas dan kemampuan memiliki nilai kurang 
dari $L_{\text {tabel }}(0,05)$, sehingga $H_{0}$ dapat diterima. Dapat disimpulkan bahwa data dari setiap kelompok berdistribusi normal.

Uji homogenitas dilakukan untuk mengetahui beberapa variansi populasi sama atau berbeda. Uji homogenitas ini menggunakan Uji Bartlett, dengan taraf signifikansi 5\% untuk setiap $X^{2}$ hitung untuk setiap kemampuan memiliki nilai kurang dari $X^{2}$ tabel, sehingga $H_{0}$ diterima. Sehingga dapat disimpulkan bahwa sampel berasal dari populasi yang homogen. Setelah mengetahui bahwa data berdistribusi normal dan berasal dari populasi yang homogen maka selanjutnya adalah uji hipotesis menggunakan Uji MANOVA.

Uji hipotesis pertama untuk mengetahui pengaruh pembelajaran flipped classroom terhadap peningkatan kemampuan berpikir kritis matematis. Data yang digunakan pada pengujian hipotesis pertama ini menggunakan data nilai $\mathrm{N}$-Gain berpikir kritis matematis pada kedua kelas penelitian. Pengujian hipotesis menggunakan uji MANOVA dengan bantuan program $R$. Hasil perhitungan manova untuk variabel berpikir kritis matematis dan motivasi belajar disajikan pada Gambar 1. Berdasarkan

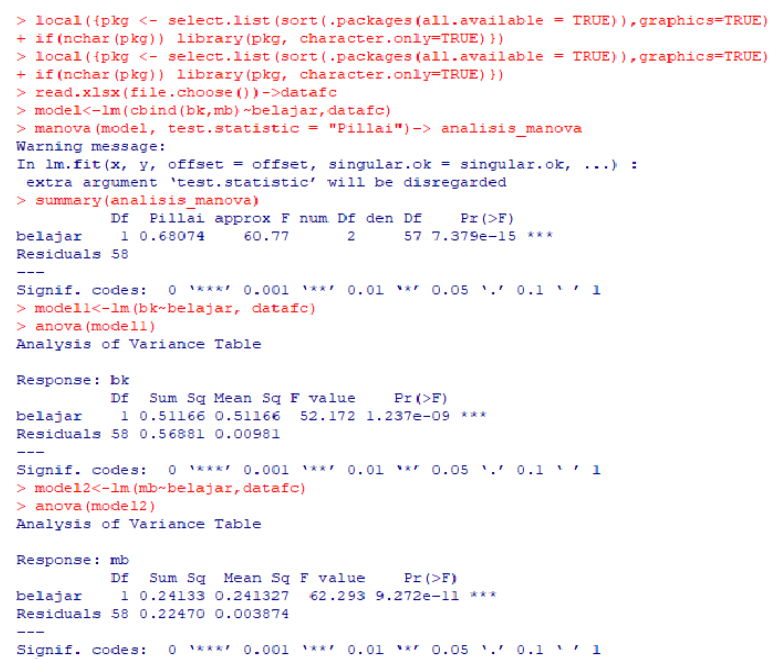

Gambar 1 Hasil Uji Manova

data yang diperoleh dan hasil analisis data, maka diperoleh hasil sebagai berikut:

\subsection{Hipotesis Pertama}

Untuk melihat ada atau tidaknya pengaruh model pembelajaran flipped classroom pada pembelajaran terhadap kemampuan berpikir kritis matematis, maka harus dipastikan bahwa data berdistribusi normal dan homogen. Dari hasil uji normalitas dengan Kolmogorov-Smirnov diperoleh hasil bahwa data berdistribusi normal. Begitu pun dengan uji homogenitas didapatkan hasil bahwa data berpikir kritis matematis dan motivasi belajar berdistribusi sama.

Berdasarkan data $N$-Gain berpikir kritis matematis, peserta didik memperoleh pembelajaran flipped classroom menunjukan peningkatan kemampuan berpikir kritis matematisnya lebih besar dibanding kemampuan berpikir kritis matematis peserta didik yang memperoleh pembelajaran ekspositori. Hal ini terlihat dari rata-rata nilai $N$ Gain kedua kelas tersebut, dimana kelas eksperimen mendapat rata nilai $N$-Gain lebih tinggi dibanding dengan kelas kontrol. Dari hasil tersebut sudah terlihat bahwa pembelajaran model flipped classroom memberi pengaruh yang lebih baik dibanding pembelajaran ekspositori terhadap berpikir kritis matematis peserta didik. Untuk membuktikan secara statistik maka dilakukan uji hipotesis menggunakan uji manova.

Berdasarkan uji manova terhadap nilai $N$ Gain berpikir kritis matematis, menghasilkan output nilai $\operatorname{Pr}(>\mathrm{F})$ sebesar $1,237 e-09^{* * *}$ dilihat dari signifikansi nilai $* * *$ yaitu akan diperoleh nilai $p$-Value sebesar 0,000 dengan derajat angka signifikansi yang dipakai yaitu 0,05 . Hal tersebut menunjukan bahwa hasil nilai signifikansi yang didapat kurang dari nilai alpha yang telah ditetapkan, sehingga $H_{0}$ ditolak dan $H_{1}$ diterima serta disimpulkan bahwa terdapat pengaruh pembelajaran flipped classroom terhadap peningkatan kemampuan berpikir kritis matematis. Hal ini sesuai dengan pembelajaran flipped classroom yang merupakan salah satu model pembelajaran yang dapat mengurangi kapasitas kegiatan pembelajaran di dalam kelas dengan memaksimalkan interaksi satu sama lain yaitu guru, peserta didik dan lingkungannya agar pembelajaran lebih bermutu dan dapat meningkatkan kemampuan berpikir kritis. 
Sedangkan di dalam pembelajaran ekspositori, materi pembelajaran langsung di transformasikan oleh pendidik kepada peserta didik. Peserta didik hanya mendengar, menyimak dan mencatat apa yang disampaikan guru tanpa terlibat aktif dalam pembelajaran. Sehingga ide yang tertuang dari peserta didik sangat terbatas.

Berdasarkan hal itu, peserta didik yang mendapat pembelajaran flipped classroom menghasilkan kemampuan berpikir kritis matematis yang lebih baik dibanding menggunakan pembelajaran ekspositori. Hasil ini juga telah sesuai dengan hipotesis penelitian, bahwa terdapat pengaruh pembelajaran flipped classroom terhadap peningkatan kemampuan berpikir kritis matematis peserta didik. Penelitian terdahulu tentang flipped classroom menunjukkan hasil model pembelajaran flipped classroom efektif digunakan untuk meningkatkan kemampuan berfikir kritis siswa pada mata pelajaran IPA [18]. Pada penelitian ini model pembelajaran flipped classroom untuk meningkatkan kemampuan kritis matematis dan motivasi belajar peserta didik.

\subsection{Analisis Hipotesis Kedua}

Berdasarkan hasil analisis $N$-Gain motivasi belajar baik eksperimen maupun kelas kontrol diperoleh nilai rata-rata $\mathrm{N}$-Gain kelas eksperimen lebih tinggi dibanding nilai rata-rata $N$-Gain kelas kontrol. Perbedaan ini menunjukkan bahwa motivasi belajar yang mendapatkan model flipped classroom lebih baik dibandingkan dengan yang mendapatkan pembelajaran ekspositori. Pengujian selanjutnya menggunakan analisis uji manova untuk dapat mengetahui pengaruh model pembelajaran flipped classroom terhadap peningkatan motivasi belajar peserta didik.

Berdasarkan uji manova terhadap nilai $N$ Gain, menghasilkan output nilai $\operatorname{Pr}(>\mathrm{F})$ sebesar $9,272 e-11^{* * *}$ dilihat dari signifikansi nilai $* *$ * yaitu akan diperoleh nilai $p-$ Value sebesar 0,000 dengan derajat angka signifikansi yang dipakai yaitu 0,05. Hal ini sesuai dengan pembelajaran flipped classroom merupakan pembelajaran yang meningkatkan aktivitas peserta didik, menjadikan peserta didik terlihat aktif dalam pembelajaran. Sehingga peserta didik mampu memahami materi dengan menyelesaikan permasalahan yang diberikan.

Sedangkan di dalam pembelajaran ekspositori, materi pembelajaran langsung di transformasikan oleh pendidik kepada peserta didik. Peserta didik hanya mendengar, menyimak dan mencatat apa yang disampaikan guru tanpa terlibat aktif dalam pembelajaran. Hal tersebut menyebabkan proses pembelajaran yang dilakukan terasa monoton dan membosankan bagi peserta didik sehingga peserta didik kurang tertarik mengikuti pembelajaran.

Berdasarkan hal itu, peserta didik yang mendapat pembelajaran menggunakan kurikulum intergrated melalui penerapan flipped classroom menghasilkan motivasi belajar yang lebih baik dibanding menggunakan pembelajaran ekspositori. Hasil ini juga telah sesuai dengan hipotesis penelitian, bahwa terdapat pengaruh pembelajaran flipped classroom terhadap peningkatan motivasi belajar peserta didik.

\subsection{Analisis Hipotesis Ketiga}

Berdasarkan hasil analisis N-Gain berpikir kritis matematis dan motivasi belajar baik eksperimen maupun kelas kontrol diperoleh nilai rata-rata $N$-Gain kelas eksperimen lebih tinggi dibandingkan nilai rata-rata $N$-Gain kelas kontrol kedua kemampuan tersebut. Perbedaan ini menunjukkan bahwa peningkatan kemampuan berpikir kritis matematis dan motivasi belajar yang mendapatkan pembelajaran model flipped classroom lebih baik dibandingkan dengan yang mendapatkan pembelajaran ekspositori. Pengujian selanjutnya menggunakan analisis uji manova untuk dapat mengetahui pengaruh pembelajaran flipped classroom terhadap peningkatan kemampuan berpikir kritis matematis dan motivasi belajar siswa.

Berdasarkan uji manova terhadap nilai $N$ Gain berpikir kritis matematis dan motivasi belajar, diperoleh hasil output nilai $\operatorname{Pr}(>\mathrm{F})$ sebesar $7,379 e-15^{* * *}$ dilihat dari 
signifikansi nilai $* * *$ yaitu akan diperoleh nilai $p-$ Value sebesar 0,000 dengan derajat angka signifikansi yang dipakai yaitu 0,05. Hal tersebut menunjukan bahwa hasil nilai signifikansi yang didapat kurang dari nilai alpha yang telah ditetapkan, sehingga $H_{0}$ ditolak dan $H_{1}$ diterima serta disimpulkan bahwa pembelajaran flipped classroom dapat berpengaruh terhadap peningkatan kemampuan berpikir kritis matematis dan motivasi belajar. Hal ini sesuai dengan pembelajaran flipped classroom yang merupakan model pembelajaran yang dapat mengurangi kapasitas kegiatan pembelajaran di dalam kelas dengan memaksimalkan interaksi satu sama lain yaitu guru, peserta didik dan lingkungannya agar pembelajaran lebih bermutu dan dapat meningkatkan kemampuan berpikir kritis peserta didik.

Sedangkan di dalam pembelajaran ekspositori, materi pembelajaran langsung di transformasikan oleh pendidik kepada peserta didik. Peserta didik hanya mendengar, menyimak dan mencatat apa yang disampaikan guru tanpa terlibat aktif dalam pembelajaran. Sehingga pembelajaran yang dilakukan terasa monoton dan membosankan bagi peserta didik yang mengakibatkan peserta didik kurang tertarik mengikuti pembelajaran dan ide yang tertuang dari peserta didik sangat terbatas.

Berdasarkan hal itu, peserta didik yang mendapat pembelajaran flipped classroom menghasilkan berpikir krtits matematis dan motivasi belajar yang lebih baik dibanding menggunakan pembelajaran ekspositori. Hasil ini juga telah sesuai dengan hipotesis penelitian, bahwa terdapat pengaruh pembelajaran flipped classroom terhadap peningkatan kemampuan berpikir kritis matematis dan motivasi belajar peserta didik.

Dari uraian hasil diatas sesuai dengan penelitian yang telah dilakukan sebelumnya oleh Adeeb M. Jarrah, Khaled Mohammed Abdel Baki Mohammed Diab model pembelajaran flipped classroom dapat meningkatkan kesiapan peserta didik sehingga mensimulasikan keterampilan keterampilan berpikir peserta didik. Seperti meningkatkan keterampilan berpikir kratif, keterampilan berpikir tingkat tinggi, dan keterampilan komunikasi dengan baik sehingga hasil belajar peserta didik meningkat [19]. Selain itu menurut Made Delina Rusnawati dalam penelitiannya terdahulu mengungkapakan bahwa pembelajaran flipped classroom membuat peserta didik mudah memahami dan lebih tertarik untuk mengikuti pembelajaran sehingga peserta didik lebih antusias dan merasa senang ketika pembelajaran berlangsung. Hal ini dapat menumbuhkan motivasi belajar bagi peserta didik yang akan berdampak positif pada hasil belajar [20].

\section{Penutup}

Hasil dari analisis dan pembahasan pada data penelitian mengenai peningkatan kemampuan berpikir kritis matematis dan motivasi belajar siswa melalui model pembelajaran Flipped Classroom berbantuan media audiovisual terhadap maka didapat bahawa:

1. Terdapat pengaruh pembelajaran flipped classroom terhadap peningkatan kemampuan berpikir kritis matematis peserta didik. Kemampuan berpikir kritis matematis peserta didik yang menggunakan pembelajaran flipped classroom lebih baik dibandingkan kemampuan berpikir kritis matematis peserta didik yang menggunakan pembelajaran ekspositori.

2. Terdapat pengaruh pembelajaran flipped classroom terhadap peningkatan motivasi belajar. Motivasi belajar peserta didik yang menggunakan pembelajaran flipped classroom lebih baik dibandingkan motivasi belajar peserta didik yang menggunakan pembelajaran ekspositori.

3. Terdapat pengaruh pembelajaran flipped classroom terhadap peningkatan kemampuan berpikir kritis matematis dan motivasi belajar. Kemampuan berpikir kritis matematis dan motivasi belajar peserta didik yang menggunakan pembelajaran flipped classroom lebih baik dibandingkan motivasi belajar peserta didik yang menggunakan pembelajaran ekspositori 


\section{Referensi}

[1] Acep Pebianto, Reyna Suhartina, Ribka Yohana dkk. Kemampuan Berpikir Kritis Matematis Siswa SMA Ditinjau dari Gender. JPMI: Jurnal Pembelajaran Matematika Inovatif, vol. 1, no. 4. (2018)

[2] Ennis, R.H. "An Outline of Goals for a Critical Thinking Curriculum". In Developing Minds: A Resource Book for Teaching Thinking. Virginia: ASCD Publication.(1985).

[3] Joko Sulianto, Nyai Cintang, dan Mira Azizah. Analisis Korelasi dan Regresi Berpikir Kritis terhadap Kemampuan Pemecahan Masalah Matematika Siswa SD Kota Semarang. Seminar Nasional Pendidikan.(2018)

[4] Nurfadillah, L., Sahtosa, C. A. H. F., \& Novaliyosi. Pengaruh Model Pembelajaran Flipped Classroom Terhadap Kemampuan Berpikir Kritis Matematis Siswa. WILANGAN : Jurnal Inovasi Dan Riset Pendidikan.(2020).

[5] Heris Hendriana, Euis Eti Rohaeti, Utari Sumarno. Hard Skills dan Soft Skills. Bandung: PT Refika Aditama.(2018).

[6] Uno, Hamzah B. Teori Motivasi Dan Pengukurannya, Analsis Di Bidang Pendidikan. Jakarta : Bumi Aksara.(2012)

[7] Santrock, John W. Psikologi Pendidikan. Edisi kedua. University of Texas at Dallas. Jakarta : Kencana.(2007).

[8] Amma Emda. Kedudukan Motivasi Belajar Siswa dalam Pembelajaran. Lantanida Journal, vol. 5, no. 2.(2017).

[9] Putri Sulistianingsih. Pengaruh Kecerdasan Emosional dan Motivasi Belajar Terhadap Kemampuan Berpikir Kritis Matematika. $J K P M$, vol. 2, no. 1.(2016).

[10] Janatin, Y., Hamid, A., Wahyu, R., \& Putra, Y. Upaya peningkatan kemampuan pemahaman konsep matematis siswa SMP dengan menggunakan pembelajaran model flipped classroom. Seminar Nasional Matematika Dan Pendidikan Matematika UIN Raden Intan Lampung, 2(1), (2019). 125-139.

[11] Saputra, M. E. A., \& Mujib, M. Efektivitas Model Flipped Classroom Menggunakan Video Pembelajaran Matematika terhadap Pemahaman Konsep. Desimal: Jurnal Matematika, $\quad$ 1(2), $\quad$ (2018). 173. https://doi.org/10.24042/djm.v1i2.2389
[12] Nurmuiza, I., Maonde, F., \& Sani, A. Pengaruh Motivasi Terhadap Hasil Belajar Matematika Siswa SMAN. JURNAL PENDIDIKAN MATEMATIKA, 6.(2015).

[13] Saputra, M. E. A., \& Mujib. Efektivitas Model Flipped Classroom Menggunakan Video Pembelajaran Matematika terhadap Pemahaman Konsep. Desimal: Jurnal Matematika, 1(2), (2018).173-179.

[14] Herreid, C. F., \& Schiller, N. A. Case Studies and Flipped Classroom. Journal of College Science Teaching 42(5), (2013). 62-66.

[15] Ozdamli, F., \& Asiksoy, G. Flipped classroom approach. World Journal on Educational Technology: Current Issues , 8 (2),(2016). 98105.

[16] Wolff, L. C., \& Chan, J. Flipped Classrooms for Legal Education. New York: Springer, (2016).

[17] Bergmann, J. and Sams, A. How the flipped classroom is radically transforming learning. The Daily Riff.(2012b).

[18] Ibrahim, M. Pemanfaatan Media Audio Visual Dalam Meningkatkan Motivasi Belajar Peserta Didik Paket C. Jurnal Ilmu Pendidikan Dan Pengajaran, 5(1).(2018).

[19] Prasetia, F. Pengaruh Media Audio Visual Terhadap Hasil Belajar Matematika. JKPM, 1(2),(2016). 257-266.

[20] Maolidah, I. S., Ruhimat, T., \& Dewi, L. Efektivitas Penerapan Model Pembelajaran Flipped Classroom Pada Peningkatan Kemampuan Berpikir Kritis Siswa. Edutcehnologia, 3(2),(2017).160-170.

[21] Jarrah, A. M., \& Diab, K. M. A. B. M. The Effect of Flipped Classroom Model o $n$ Students Achievement in the New 2016 Scholastic Assessment Test Mathematics Skills. The Journal of Social Sciences Research, 5, (2019). 769-777.

[22] Rusnawati, M. D. Implementasi Flipped Classroom Terhadap Hasil dan Motivasi Belajar Siswa. Jurnal Ilmiah Dan Pembelajaran, 4(April), (2020). 139-150. 